\title{
Analysis of Student Motivation in Online Learning for the Tourism and Hospitality Management Information System Course during the Covid- 19 Pandemic
}

\author{
Dedi Joko Purnomo', Andi Hallang Lewa ${ }^{2}$, Izza Ulumuddin Ahmad Asshofi ${ }^{3}$ \\ ${ }^{1}$ Universitas Dian Nuswantoro, Semarang, Indonesia \\ ${ }^{2}$ Universitas Dian Nuswantoro, Semarang, Indonesia \\ ${ }^{3}$ Universitas Dian Nuswantoro, Semarang, Indonesia
}

\begin{tabular}{c}
\hline Article History \\
\hline Submitted date: \\
2021-08-01 \\
Accepted date: \\
2021-09-21 \\
Published date: \\
2021-11-17 \\
\hline Keywords:
\end{tabular}

student motivation; covid19 pandemic; online learning

\begin{abstract}
The global pandemic of the infectious disease COVID-19 has caused concern for all citizens of the world. Not only in the health sector, but also in other sectors, be it trade, economy, security, politics, transportation, and education. The policy of closing schools and colleges had to be taken to prevent the spread of the Corona virus. Even though at the beginning of the pandemic, some countries are still trying to open schools as usual. However, in the end, due to the increasingly widespread pandemic, measures to close schools and universities had to be taken to save the education sector. The purpose of this study is to analyze students' online learning motivation in the Tourism and Hospitality Management Information System practice course which is usually carried out in a computer laboratory during the global pandemic of the COVID 19 infectious disease. This research conducted using a descriptive qualitative research design. Positive responses from the lecture aspect, the ability of lecturers, facilities, and infrastructure also have a positive effect on student motivation in undergoing online lectures. The level of activity and motivation is high with the average percentage of student attendance in 1 semester reaching $92 \%$ and the collection of assignments is $85 \%$. However, the limited financial ability of students and geographical conditions with minimal internet connections are the main obstacles to online lectures.
\end{abstract}

\section{Kata Kunci:}

motivasi mahasiswa; pandemi covid-19; sistem pembelajaran daring

\section{Abstrak}

Analisis Motivasi Pembelajaran Daring pada Mata Kuliah Tourism and Hospitality Management Information System di Masa Pandemi Covid-19

Pandemik global penyakit menular COVID-19 telah menimbulkan keresahan bagi seluruh warga dunia. Tidak hanya di sektor kesehatan, tetapi juga merambah ke sektor lainnya, baik itu perdagangan, ekonomi, keamanan, politik, transportasi, dan pendidikan. Kebijakan menutup sekolah dan perguruan tinggi terpaksa diambil untuk mencegah penyebaran virus Corona. Walaupun diawal pandemi merebak, beberapa negara masih berupaya untuk membuka sekolah seperti biasa. Namun, pada akhirnya karena pandemi yang kian menyebar, langkah penutup sekolah dan perguruan tinggi harus dilakukan untuk menyelamatkan sektor pendidikan. Tujuan penelitian ini adalah untuk menganalisa motivasi belajar daring mahasiswa pada matakuliah praktik Tourism and Hospitality Management Information System yang biasanya dilakukan di laboratorium komputer di masa pandemik global penyakit menular COVID 19 ini dilakukan secara daring. Penelitian ini telah dilakukan dengan menggunakan desain penelitian kualitatif deskriptif. Respon positif dari aspek perkuliahan, kemampuan 
dosen, sarana dan prasarana juga berpengaruh positif terhadap motivasi mahasiswa dalam menjalani perkuliahan online. Tingkat keaktifan dan motivasi tinggi dengan rerata persentase kehadiran mahasiswa dalam 1 semester mencapai $92 \%$ dan pengumpulan tugas $85 \%$. Akan tetapi, kemampuan secara finansial mahasiswa yang terbatas, dan kondisi geografis dengan koneksi internet yang minim menjadi kendala utama dari perkuliahan daring.

\section{Pendahuluan}

Pandemi Covid-19 pada bulan Maret 2021 berdampak terhadap perubahan aktivitas belajarmengajar. Tak terkecuali di Indonesia, sejak bulan Maret aktivitas pembelajaran daring menjadi sebuah pilihan kementerian pendidikan dan kebudayaan untuk mencegah penyebaran virus Covid-19 semakin meluas (https://www.kompas.com, 2020). Pandemi virus korona baru (Covid-19) berpengaruh pada bidang pendidikan tinggi. Pengaruh Covid-19 berpengaruh pada proses belajar mengajar, penerimaan mahasiswa baru, pembiayaan kuliah, dan lainnya. Hanya butuh waktu 25 hari sejak pengumuman pasien positif pertama di Indonesia untuk mampu memaksa 834 perguruan tinggi di Indonesia hijrah ke daring (https://www.tribunnewswiki.com, 2020).

Pemerintah melalui Kementerian Pendidikan dan Kebudayaan telah menerbitkan Surat Edaran Nomor 3 Tahun 2020 tentang Pencegahan Covid-19 pada Satuan Pendidikan (https://www.kemdikbud.go.id, 2020). Pembelajaran secara daring menjadi solusi terbaik terhadap kegiatan belajar mengajar di tengah pandemi COVID-19. Meski telah diputuskan pemerintah, pembelajaran daring ini masih menimbulkan banyak kendala karena banyak perguruan tinggi merasa tidak siap dengan kepindahan tersebut. Menurut beberapa dosen, pembelajaran daring sebagian besar hanya efektif untuk penugasan, sedangkan untuk membuat mahasiswa memahami materi pembelajaran lewat daring relatif lebih sulit. Selain itu, penguasaan perangkat teknologi dan taraf ekonomi setiap mahasiswa berbeda-beda. Tidak semua mahasiswa memiliki fasilitas yang menunjang kegiatan pembelajaran daring. Koneksi internet yang tidak memadai, perangkat yang tidak mendukung, dan kuota internet yang mahal menjadi penghambat pembelajaran daring. Namun, proses pendidikan harus terus berlanjut. Setiap penyelenggara pendidikan memiliki aturan dan kebijakan masing-masing dalam menyikapi aturan ini.

Beberapa penelitian telah dilakukan terkait dengan pembelajaran daring. Fitriani, Fauzi, dan Sari (2020) dalam penelitianya tentang motivasi belajar mahasiswa pada pembelajaran daring selama pandemik covid-19 menunjukkan bahwa motivasi belajar mahasiswa sangat baik, dengan skor presentase motivasi mencapai 80,27 \%, Firman dan Rahman (2020) dalam penelitiannya menyatakan bahwa: (1) mahasiswa telah memiliki fasilitas-fasilitas dasar yang dibutuhkan untuk mengikuti pembelajaran daring; (2) pembelajaran daring memiliki fleksibilitas dalam pelaksanaannya dan mampu mendorong munculnya kemandirian belajar dan motivasi untuk lebih aktif dalam belajar; dan (3) pembelajaran jarak jauh mendorong munculnya perilaku social distancing dan meminimalisir munculnya keramaian mahasiswa sehingga dianggap dapat mengurangi potensi penyebaran Covid19 di lingkungan kampus. Tantri (2018) dalam penelitiannya mengidentifikasi 3 aspek kehadiran sosial, yaitu aspek keterhubungan, aspek belajar, dan aspek sosial emosional. Hasil penelitian Tantri menunjukkan bahwa semua aspek memiliki dampak positif dari sudut pandang siswa. Sofiana dan Rozaq (2019) menganalisis penerapan pembelajaran daring kombinasi berbasis WhatsApp pada kelas karyawan program studi teknik informatika. Hasil penelitian mereka menunjukkan bahwa pembelajaran daring meningkatkan minat mahasiswa sebesar $89 \%$ dan memiliki efektivitas sebesar 78\% daripada pembelajaran konvensional. Emmilia dan Nugroho (2020), menyatakan bahwa perkuliahan daring dapat memotivasi mahasiswa dengan baik, hal ini ditunjukkan dengan pilihan jawaban terbanyak adalah termotivasi dan sangat termotivasi. Hasil penelitian menunjukkan bahwa motivasi mahasiswa saat mengikuti perkuliahan daring sebesar $71 \%$ dan efektivitas perkuliahan sebesar 76,4\%. Maulana \& Hamidi (2020) menunjukkan bahwa persepsi mahasiswa terhadap pembelajaran daring pada mata kuliah praktik bersifat positif, dengan rincian aspek belajar 
mengajar sebesar 66,4\%, aspek kapabilitas (kemampuan dosen) sebesar 74,6\%, dan aspek sarana dan prasarana sebesar $72,7 \%$.

Penelitian terdahulu sebagian besar dilakukan pada mata kuliah teori di institusi pendidikan tinggi umum, sedangkan penelitian terkait pembelajaran daring pada pada mata kuliah praktik masih kurang. Oleh sebab itu, penelitian ini lebih difokuskan pada mata kuliah praktik dengan tujuan untuk mengetahui motivasi belajar mahasiswa.

Perkuliahan berbasis daring atau kuliah daring, disebut juga E-Learning adalah proses belajar dan mengajar dengan menggunakan teknologi informasi dan komunikasi, dengan menggunakan media cetak (modul) maupun noncetak (audio/video), komputer/internet, siaran radio, dan televisi.

Dalam penerapan kuliah daring, dosen dan mahasiswa memiliki perannya masing-masing. Dosen memiliki peran sebagai fasilitator dan pembimbing dalam kegiatan pembelajaran, sedangkan peserta didik (siswa dan mahasiswa) memiliki peran sebagai konstruktor pengetahuan, pembelajar mandiri (independent learners), dan pemecah masalah (problem solvers) (Maudiarti, 2018).

Dalam perkuliahan daring, mahasiswa tidak dituntut harus selalu datang ke kampus. Kuliah daring juga merupakan salah satu sarana pembelajaran interaktif. Dosen dan mahasiswa dapat melakukan komunikasi dengan menggunakan media internet. Dosen dapat memberikan materi perkuliahan, baik berupa file, video, maupun tulisan (teks). Dengan kuliah daring, seorang dosen juga dapat mengajar di beberapa tempat secara bersamaan. Mahasiswa dapat memperoleh materi perkuliahan berupa file atau bacaan dari dosen yang bersangkutan, mengirimkan pertanyaan kepada dosen mata kuliah tersebut, mengirimkan kontak pada mahasiswa lain, melihat informasi dari dosen yang bersangkutan, dan melakukan ujian pada waktu yang telah ditetapkan (https://sevima.com, 2019).

Menurut Noveandini dan Wulandari (2010) perkuliahan daring memiliki beberapa dampak positif, yaitu:

1) Meningkatkan interaksi belajar antara pembelajar dengan pengajar(enhance interactivity);

2) Memungkinkan belajar di mana saja dan kapan saja (time and place flexibility);

3) Menjangkau peserta didik dalam cakupan yang luas (potential to reach a global audience);

4) Mempermudah penyimpanan dan penyempurnaan dalam belajar (easy updating of content as well as archivable capabilities);

5) Membangun Komunitas.

Ada 3 komponen yang harus disiapkan dalam perkuliahan daring (Noveandini \& Wulandari, 2010). Komponen tersebut adalah:

1) Infrastruktur: Infrastruktur e-Learning dapat berupa personal computer (PC), jaringan komputer, internet dan perlengkapan multimedia;

2) Sistem dan Aplikasi: Sistem perangkat lunak yang mem-virtualisasi proses belajar mengajar konvensional. Bagaimana pembuatan materi atau konten, forum diskusi dan segala fitur yang berhubungan dengan manajemen proses belajar mengajar;

3) Konten: Konten dan bahan ajar yang ada pada e-Learning system (Learning Management System). Konten dan bahan ajar ini bisa dalam bentuk Multimedia-based Content (konten berbentuk multimedia interaktif) atau Text-based Content (konten berbentuk teks seperti pada buku pelajaran biasa).

Motivasi diartikan sebagai kekuatan (energi) seseorang yang dapat menimbulkan tingkat kemauan dalam melaksanakan suatu kegiatan. Kemauan baik yang bersumber dari dalam diri individu itu sendiri (motivasi intrinsik) maupun dari luar individu (motivasi ekstrinsik). Seberapa kuat 
motivasi yang dimiliki individu akan banyak menentukan kualitas perilaku yang ditampilkannya, baik dalam konteks belajar, bekerja maupun dalam kehidupan lainnya (Suprihatin, 2015).

\section{Metode}

Penelitian ini merupakan penelitian campuran kuantitatif dan kualitatif. Metode kuantitatif digunakan dalam rangka pengumpulan data yang kemudian hasilnya dianalisis berdasarkan metode kualitatif. Populasi pada penelitian ini adalah mahasiswa Program Sarjana Terapan Pengelolaan Perhotelan Universitas Dian Nuswantoro (UDINUS) semester 3. Sampel diambil dengan menggunakan teknik purposive sampling yang hanya berfokus pada mahasiswa yang sedang mengambil mata kuliah praktik Tourism and Hospitality management Information System sejak diberlakukan pembelajaran daring karena pandemi COVID-19. Data penelitian diperoleh dengan menggunakan kuesioner yang diisi secara daring oleh mahasiswa dengan menggunakan Google Form. Teknik analisis data yang digunakan dalam penelitian ini adalah analisis kualitatif yang terdiri atas pengumpulan data, reduksi data, penyajian data, dan penarikan kesimpulan. Tingkat persepsi mahasiswa dalam penelitian ini mengacu pada standar pengukuran yaitu: Negative jika rerata total butir komponen $\leq 40 \%$ dan Positive jika rerata total butir komponen $\geq 40 \%$ (Maulana \& Hamidi, 2020).

\section{Hasil dan Pembahasan}

Kuesioner diisi oleh mahasiswa secara daring menggunakan google form oleh mahasiswa Program Sarjana Terapan Pengelolaan Perhotelan UDINUS semester 3. Mata kuliah praktik yang dipilih adalah Tourism and Hospitality Management Information System, mata kuliah tersebut dipilih karena perangkat yang digunakan hanya menggunakan perangkat komputer dan memungkinkan untuk dilaksanakan perkuliahan daring. Responden berjumlah 37 mahasiswa dari 2 kelas yang berbeda. Deskripsi responden dapat dilihat di tabel 1.

Tabel 1: Jumlah Responden

[Sumber: kulino.dinus.ac.id]

Deskripsi Responden

\begin{tabular}{cccc}
\hline \multirow{4}{*}{ Kelas } & \multicolumn{2}{c}{ Jumlah Responden } \\
& \multicolumn{1}{c}{ C13.3.1 } & $\mathrm{C} 13.3 .2$ & Total \\
\cline { 2 - 4 } & $(\%)$ & $(\%)$ & $(\%)$ \\
\cline { 2 - 4 } & 22 & 15 & 37 \\
\cline { 2 - 4 } & $59 \%$ & $41 \%$ & $100 \%$ \\
\hline \multirow{3}{*}{ Jenis Kelamin } & Laki Laki & Perempuan & Total \\
\cline { 2 - 4 } & $(\%)$ & $(\%)$ & $(\%)$ \\
\cline { 2 - 4 } & 14 & 23 & 37 \\
\cline { 2 - 4 } & $38 \%$ & $62 \%$ & $100 \%$ \\
\hline
\end{tabular}

Kuisioner terdiri dari 3 bagian proses perkuliahan, kompetensi dosen, sarana prasarana dengan total 12 pertanyaan. Setiap pertanyaan menggunakan skala likert, yaitu: Sangat Tidak Setuju/STS, Tidak Setuju/TS, Biasa Saja/BS, Setuju/S), dan Sangat Setuju/ST. Menurut (Sugiyono, 2018) bahwa skala likert digunakan sebagai alat untuk mengukur sikap, pendapat, dan persepsi individu atau sekolompok orang terhadap fenomena sosial. Pertanyaan Kuesioner dapat dilihat di tabel 2 dan Grafik kuesioner setiap pertanyaan dapat dilihat pada Grafik 1 sampai dengan Grafik 12 
Tabel 2: Pertanyaan Kuesioner

\begin{tabular}{|c|c|c|c|c|c|c|c|c|c|c|c|}
\hline No & Item & & STS & & TS & & B & & $\mathrm{S}$ & & SS \\
\hline & A. Proses Perkuliahan & $\mathrm{f}$ & $\%$ & $\mathrm{f}$ & $\%$ & $f$ & $\%$ & $f$ & $\%$ & $\mathrm{f}$ & $\%$ \\
\hline 1 & $\begin{array}{l}\text { Proses Pelaksanaan Perkuliah daring dapat } \\
\text { diakses secara mudah oleh mahasiswa }\end{array}$ & 0 & $0,0 \%$ & 2 & $5,4 \%$ & 5 & $\begin{array}{c}13,5 \\
\%\end{array}$ & 21 & $\begin{array}{c}56,8 \\
\%\end{array}$ & 9 & $\begin{array}{c}24,3 \\
\%\end{array}$ \\
\hline 2 & $\begin{array}{l}\text { Proses Perkuliah Daring dilaksanakan tepat } \\
\text { waktu dan sesuai dengan jadwal }\end{array}$ & 0 & $0,0 \%$ & 2 & $5,4 \%$ & 9 & $\begin{array}{c}24,3 \\
\%\end{array}$ & 17 & $\begin{array}{c}45,9 \\
\%\end{array}$ & 9 & $\begin{array}{c}24,3 \\
\%\end{array}$ \\
\hline 3 & $\begin{array}{l}\text { Proses Perkuliahan secara Daring dapat } \\
\text { menambah pemahaman teori dan } \\
\text { keterampilan }\end{array}$ & 2 & $5,4 \%$ & 4 & $\begin{array}{c}10,8 \\
\%\end{array}$ & 11 & $\begin{array}{c}29,7 \\
\%\end{array}$ & 16 & $\begin{array}{c}43,2 \\
\%\end{array}$ & 5 & $\begin{array}{c}13,5 \\
\%\end{array}$ \\
\hline 4 & $\begin{array}{l}\text { Materi kuliah yang disajikan secara Daring } \\
\text { sesuai dengan Kontrak Perkuliahan/RPS }\end{array}$ & 0 & $0,0 \%$ & 0 & $0,0 \%$ & 4 & $\begin{array}{c}10,8 \\
\%\end{array}$ & 27 & $\begin{array}{l}73,0 \\
\%\end{array}$ & 6 & $\begin{array}{c}16,0 \\
\%\end{array}$ \\
\hline \multirow[t]{2}{*}{5} & am mengirimkan tugas & 0 & $0,0 \%$ & 1 & $2,7 \%$ & 8 & $\begin{array}{c}21,6 \\
\%\end{array}$ & 19 & $\begin{array}{c}51,4 \\
\%\end{array}$ & 9 & $\begin{array}{c}24,3 \\
\%\end{array}$ \\
\hline & B. Kompetensi dosen & & & & & & & & & & \\
\hline 6 & $\begin{array}{l}\text { Dosen selalu mendampingi pada saat } \\
\text { pembelajaran Daring hingga selesai }\end{array}$ & 0 & $0.0 \%$ & 0 & $0,0 \%$ & 6 & $\begin{array}{c}16,2 \\
\%\end{array}$ & 23 & $\begin{array}{c}62,2 \\
\%\end{array}$ & 8 & $\begin{array}{c}21,6 \\
\%\end{array}$ \\
\hline 7 & $\begin{array}{l}\text { Dosen menjelaskan arah dan tujuan dalam } \\
\text { setiap pembelajaran Daring }\end{array}$ & 0 & $0,0 \%$ & 0 & 0 & 4 & $\begin{array}{c}10,8 \\
\%\end{array}$ & 22 & $\begin{array}{c}59,5 \\
\%\end{array}$ & 11 & $\begin{array}{c}29,7 \\
\%\end{array}$ \\
\hline 8 & $\begin{array}{l}\text { Dosen memberikan kesempatan mahasiswa } \\
\text { untuk bertanya dan berdiskusi }\end{array}$ & 0 & $0,0 \%$ & 0 & $0,0 \%$ & 3 & $8,1 \%$ & 20 & $\begin{array}{c}52,1 \\
\%\end{array}$ & 15 & $\begin{array}{c}39,8 \\
\%\end{array}$ \\
\hline 9 & $\begin{array}{l}\text { Dosen memberikan respon terhadap } \\
\text { pertanyaan yang muncul selama } \\
\text { perkuliahan secara Daring }\end{array}$ & 0 & $0,0 \%$ & 0 & $0,0 \%$ & 4 & $5,4 \%$ & 21 & $\begin{array}{c}56,8 \\
\%\end{array}$ & 14 & $\begin{array}{c}37,8 \\
\%\end{array}$ \\
\hline \multirow[t]{2}{*}{10} & $\begin{array}{l}\text { Tingkat pemahaman anda secara umum } \\
\text { terhadap mata kuliah yang diberikan secara } \\
\text { Daring }\end{array}$ & 0 & $0,0 \%$ & 2 & $5,1 \%$ & 13 & $\begin{array}{c}33,1 \\
\%\end{array}$ & 21 & $\begin{array}{c}56,8 \\
\%\end{array}$ & 2 & $5,4 \%$ \\
\hline & C. Sarana Prasarana & & & & & & & & & & \\
\hline 11 & $\begin{array}{l}\text { Materi sudah tersedia dengan Baik pada } \\
\text { media pembelajaran Daring yg digunakan }\end{array}$ & 0 & $0,0 \%$ & 0 & $0,0 \%$ & 4 & $\begin{array}{c}10,8 \\
\%\end{array}$ & 26 & $\begin{array}{c}70,3 \\
\%\end{array}$ & 7 & $\begin{array}{c}18,9 \\
\%\end{array}$ \\
\hline 12 & $\begin{array}{l}\text { Saya memiliki perangkat/peralatan untuk } \\
\text { melakukan praktikum di rumah }\end{array}$ & 2 & $3,4 / 0$ & 3 & 8 & 9 & $\begin{array}{c}24,3 \\
\%\end{array}$ & 15 & $\begin{array}{c}40,5 \\
\%\end{array}$ & 8 & $\begin{array}{c}21,6 \\
\%\end{array}$ \\
\hline
\end{tabular}

\subsection{Proses Perkuliahan}

Sebelum pandemi Covid 19, proses perkuliahan dilakukan dengan tatap muka. Dalam perkuliahan ini kesemuanya tersedia dengan baik mulai dari jadwal, materi, dan proses lainnya. Sebaliknya, di masa pandemi kebutuhan untuk itu disediakan dalam bentuk daring. Hasil kuisioner yang diisi mahasiswa diketahui bahwa proses pelaksanaan perkuliah daring dapat diakses secara mudah oleh mahasiswa sebesar $81,1 \%$, mahasiswa yang mengalami sedikit kesulitan sebesar 13,5\% dan terdapat $5,4 \%$ mahasiswa sangat kesulitan dalam mengakses perkuliahan secara daring. Kesulitan tersebut dikarenakan koneksi yang tidak stabil dan kondisi tempat tinggal yang minim jaringan internet. Dari segi kesesuaian jadwal dan ketepatan waktu, 5,4\% mahasiswa berpendapat bahwa ada perkuliahan daring yang tidak tepat waktu dan jadwal yang berubah. Perubahan jadwal kebanyakan disebabkan pergantian jadwal yang mendadak karena terkendala teknis. Dari segi pemahaman teori dan penguasaan keterampilan $16.2 \%$ mahasiswa mengalami kesulitan memahami materi praktikum, 
Purnomo, D. J., Lewa, A. H., Asshofi, I. U. A., (2021). Analysis of Student Motivation in Online Learning for the Tourism and Hospitality Management Information System Course during the Covid-19 Pandemic. LITE: Jurnal Bahasa, Sastra, dan Budaya 17 (2), 1-20. https://doi.org/10.33633/lite.v17i2.5061

karena banyaknya tugas dan terkendala teknis dalam penyampaian. Dari segi kesesuaian dengan Kontrak Perkuliahan/RPS, 89,2\% mahasiswa menyatakan sesuai.

\section{Grafik 1. Kemudahan Akses}

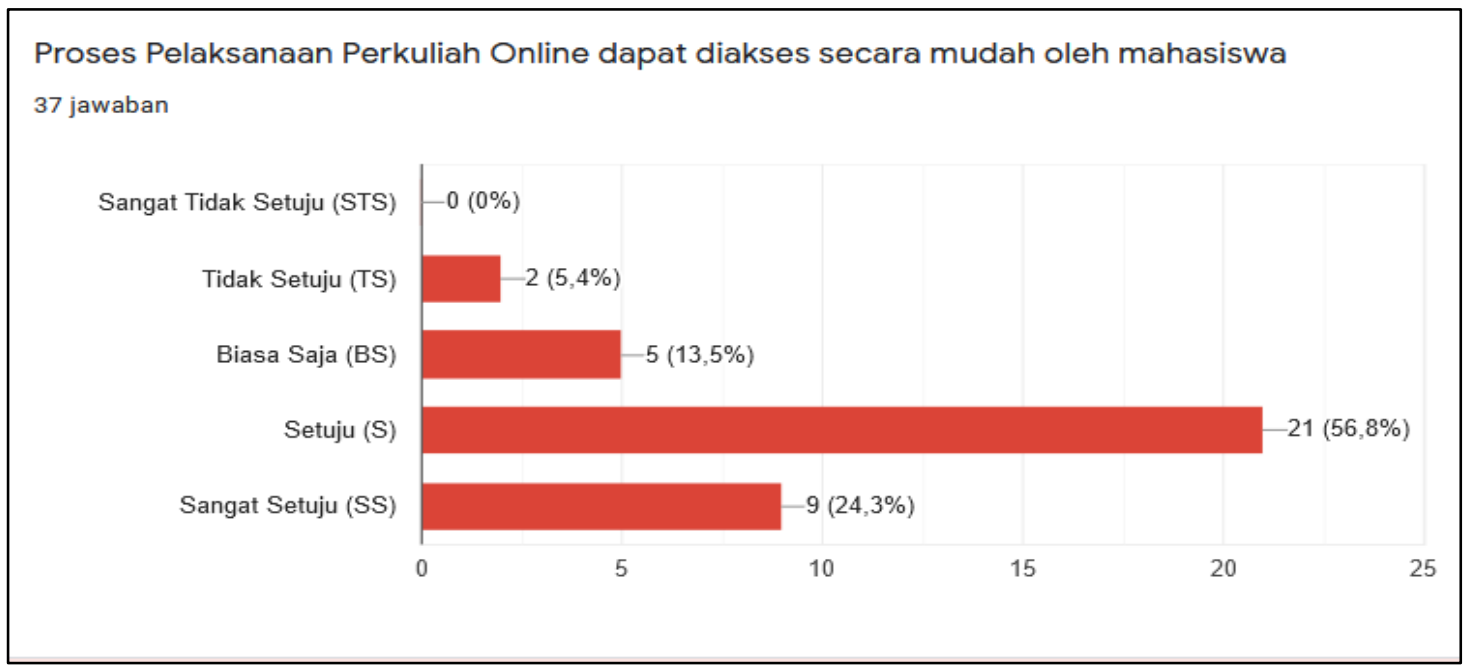

Grafik 2. Waktu dan Jadwal

\section{Proses Perkuliah Online dilaksanakan tepat waktu dan sesuai dengan jadwal}

37 jawaban

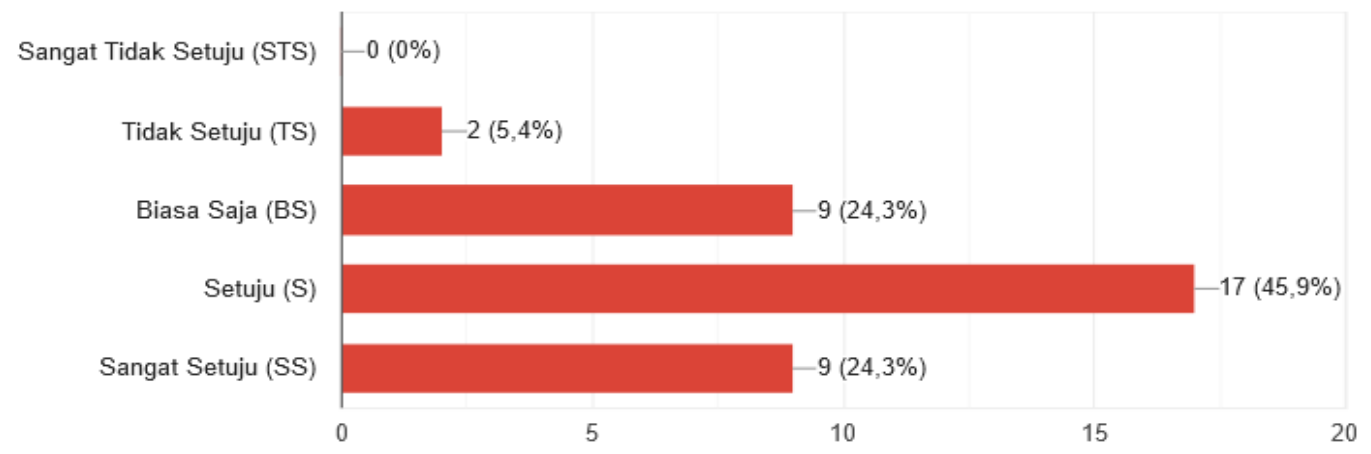

\section{Grafik 3. Pemahaman teori dan keterampilan}

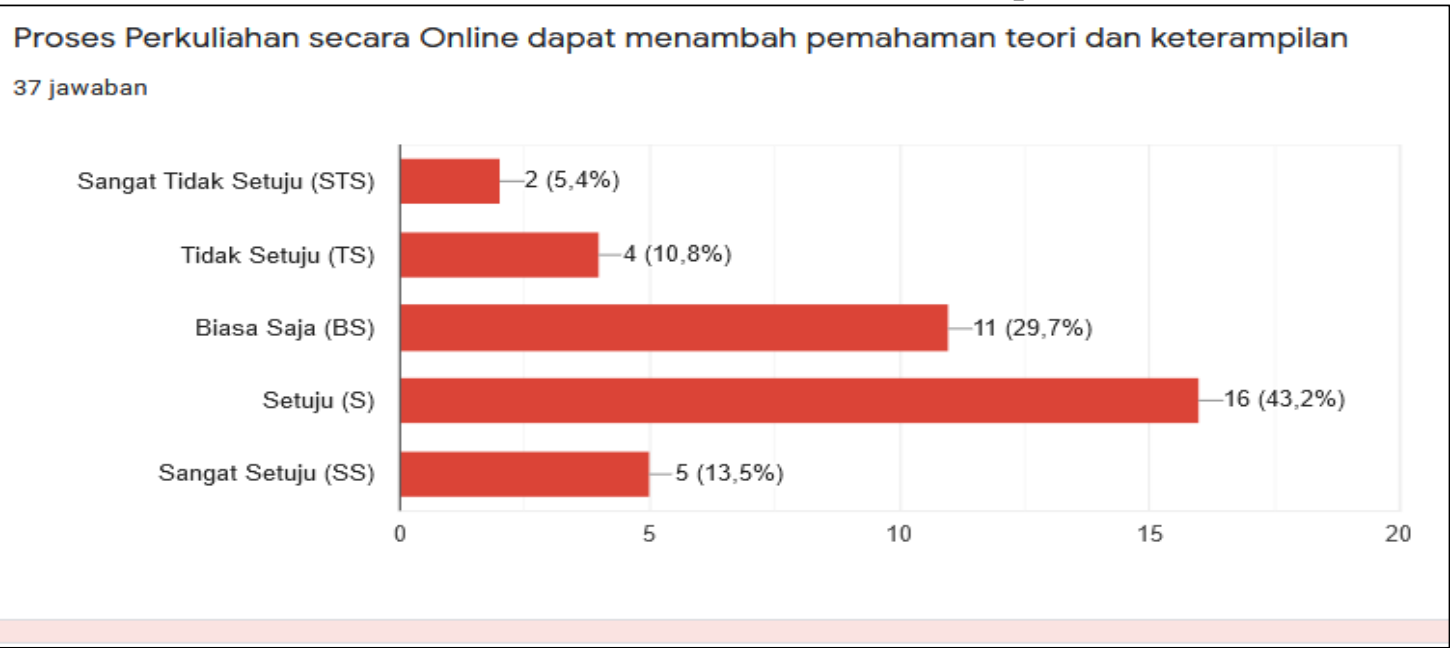

Copyright $(\underset{2}{ } 2021$ Dedi Joko Purnomo, Andi Hallang Lewa, Izza Ulumuddin Ahmad Asshofi 


\section{Grafik 4. Kesesuaian RPS}

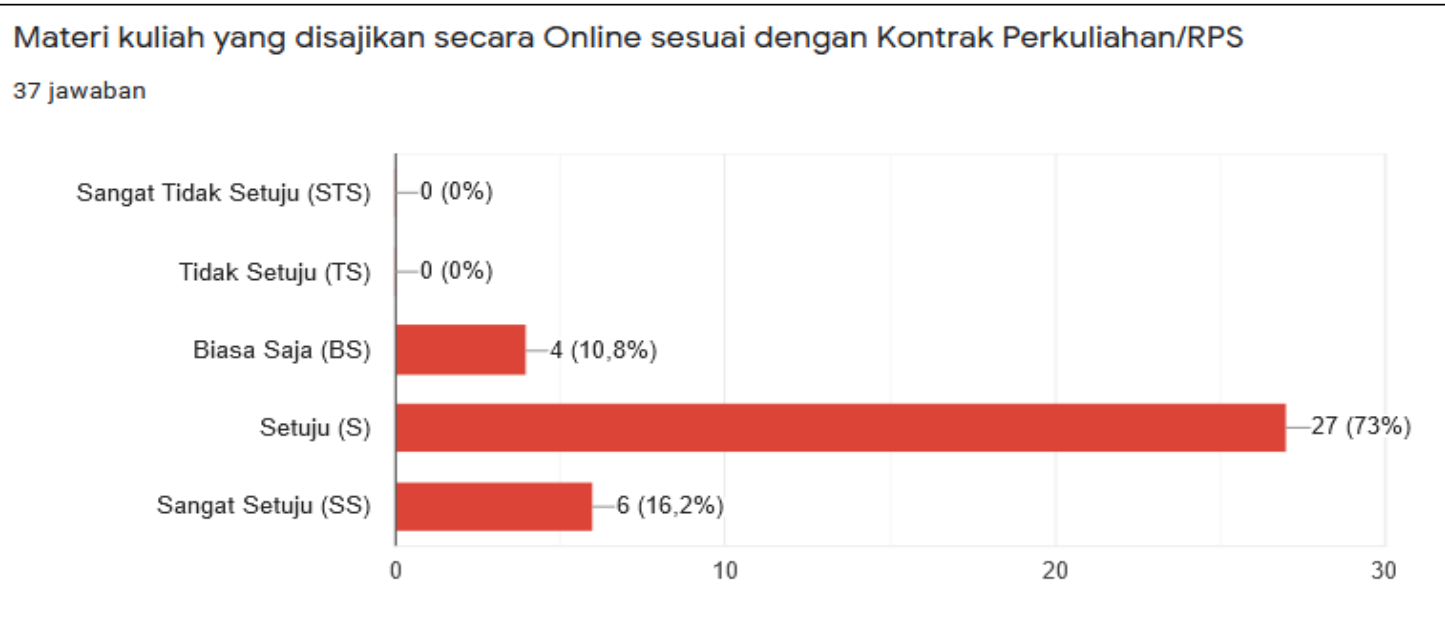

Secara menyeluruh proses perkuliahan mendapatkan persentase rata-rata sebesar $74,7 \%$ sehingga dapat dikategorikan respon mahasiswa terhadap proses perkuliahan pada perkuliahan daring untuk mata kuliah praktik adalah positif.

\subsection{Kompetensi Dosen}

Peran dosen yang utama dalam pembelajaran daring adalah sebagai fasilitator. Dosen harus mampu memfasilitasi dan menyediakan sarana yang dapat mengilhami mahasiswa dalam berpikir aktif dan kreatif. Ia juga harus mampu menyampaikan ilmu pengetahuan kepada peserta didik dalam lingkup kegiatan belajar mengajar. Dari hasil kuisioner yang diisi mahasiswa diketahui bahwa 83,8\% mahasiswa menyatakan dosen mendampingi mahasiswa pada saat perkuliahan daring. 91,9\% mahasiswa menyatakan dosen memberikan kesempatan mahasiswa untuk berdiskusi dan bertanya sehubungan dengan materi yang disampaikan, 89,2\% mahasiwwa menyakan dosen menjelaskan arah dan tujuan dalam setiap pembelajaran daring, 94,6\% mahasiswa menyatakan dosen merespon setiap pertanyaan yang disampaikan mahasiswa selama perkuliahan secara daring. Secara umum, tingkat pemahaman terhadap mata kuliah yang diberikan secara daring adalah 62,2\%. 35,1\% mahasiswa menyatakan sedikit mengalami kesulitan, 5,4\% mengalami kesulitan. Hal tersebut dikarenakan kesulitan pemahaman teori dari materi yang diberikan dan terbatasnya penjelasan karena durasi waktu dari aplikasi tatap muka daring yang digunakan.

\section{Grafik 5. Kehadiran dosen}

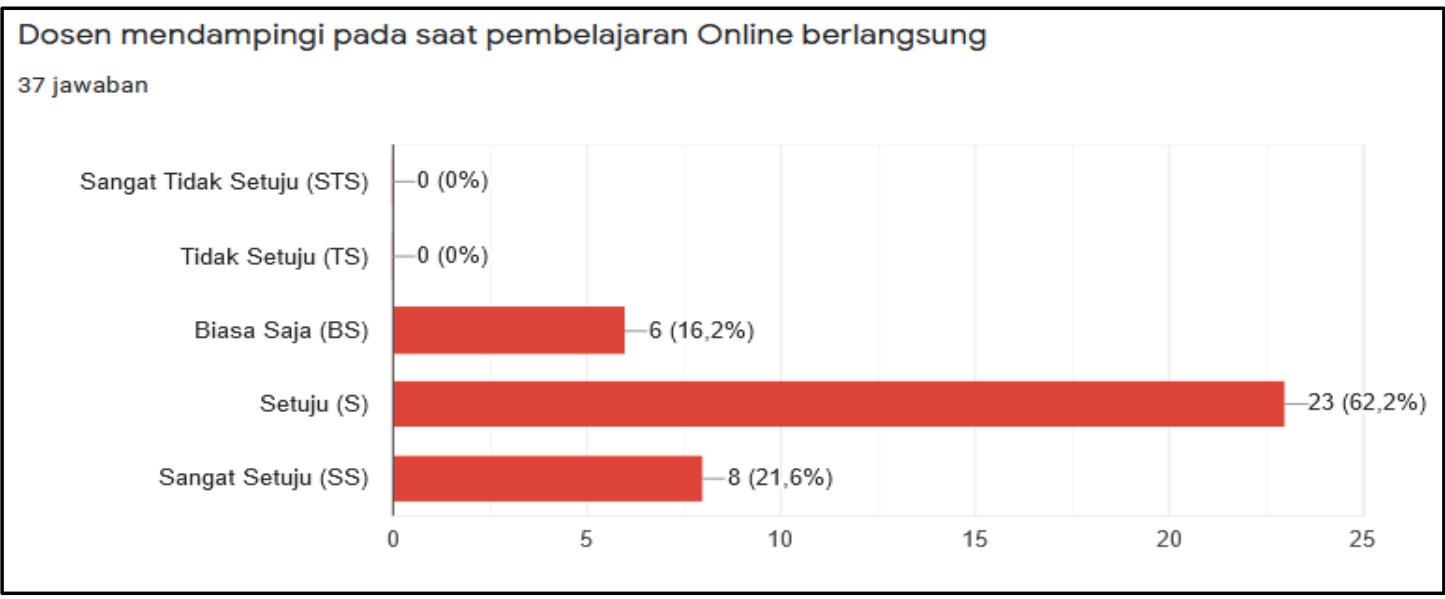


Purnomo, D. J., Lewa, A. H., Asshofi, I. U. A., (2021). Analysis of Student Motivation in Online Learning for the Tourism and Hospitality Management Information System Course during the Covid-19 Pandemic. LITE: Jurnal Bahasa, Sastra, dan Budaya 17 (2), 1-20. https://doi.org/10.33633/lite.v17i2.5061

\section{Grafik 6. Kesempatan bertanya dan berdiskusi}

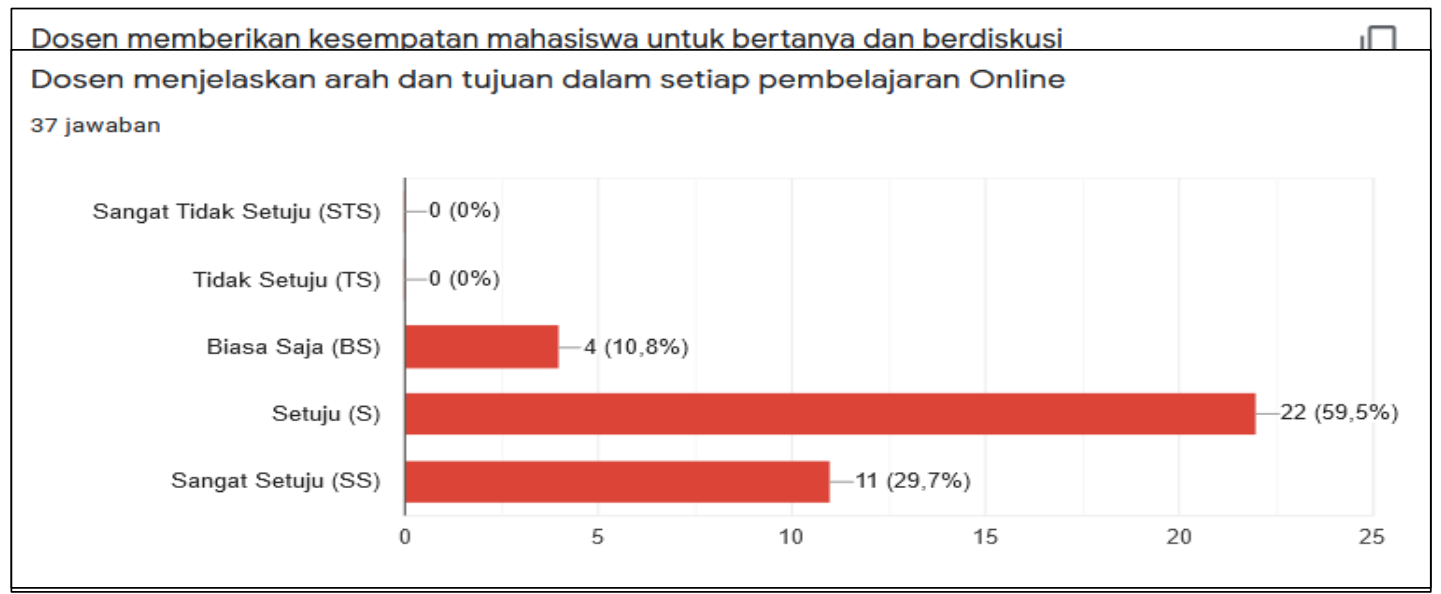

Grafik 7. Penjelasan arah dan tujuan pembelajaran

\section{Grafik 8. Respon pertanyaan}

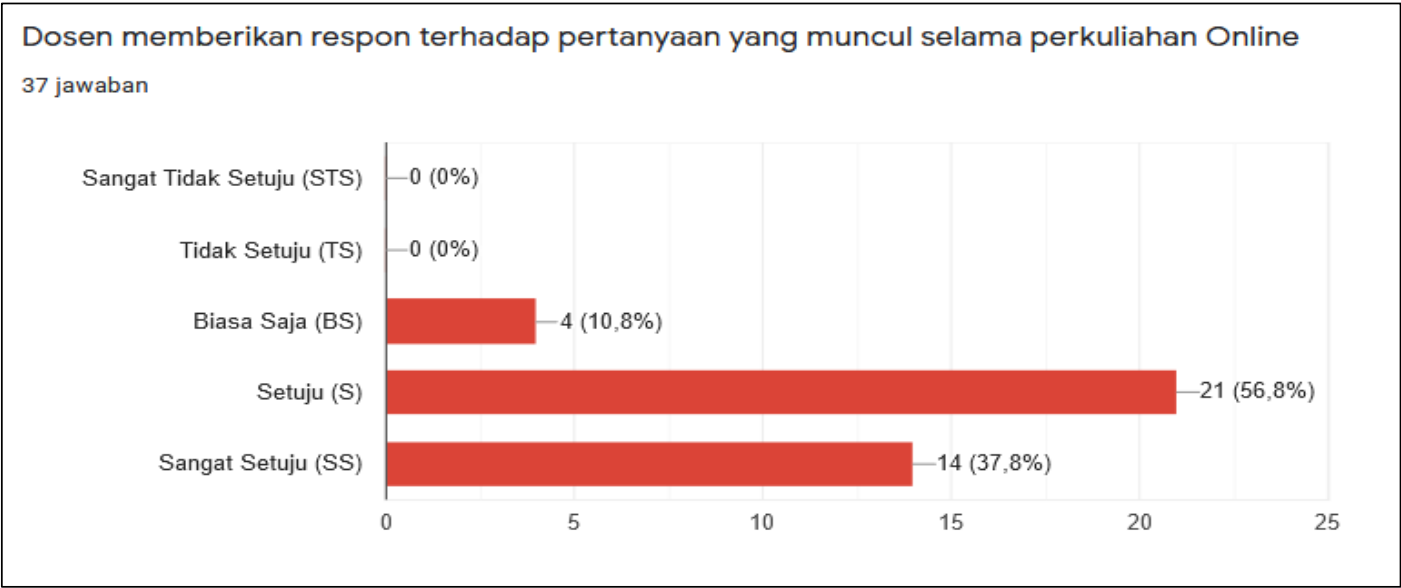

Grafik 9. Tingkat pemahaman secara umum

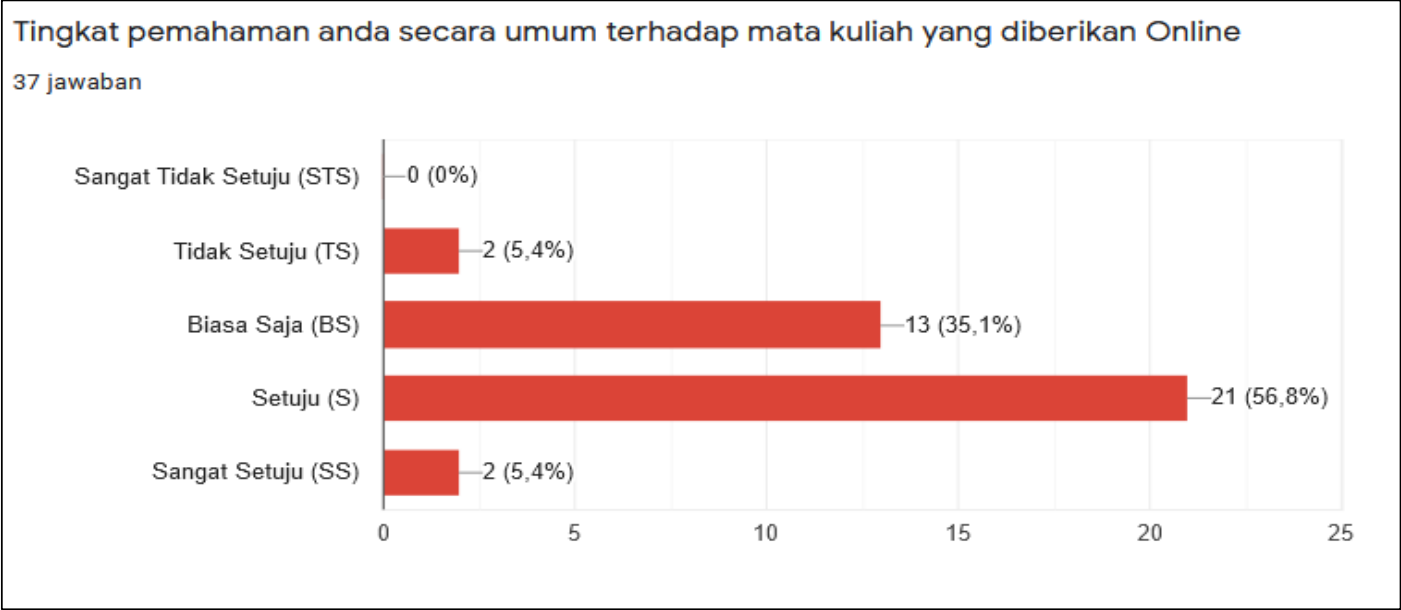


Secara keseluruhan aspek kompetensi dosen mendapatkan persentase rerata sebesar $84,3 \%$ sehingga dapat dikategorikan respon mahasiswa terhadap kemampuan dosen pada perkuliahan daring untuk mata kuliah praktik adalah positif.

\subsection{Sarana dan Prasarana}

Sarana dan prasarana adalah merupakan alat atau bagian yang memiliki peranan sangat penting bagi keberhasilan dan kelancaran suatu proses, termasuk juga dalam lingkup pendidikan (Rahayu, 2019). Dari hasil kuisioner yang diisi mahasiswa diketahui 86,4\% mahasiswa menyatakan materi sudah tersedia dengan baik pada media pembelajaran daring. 62,1\% mahasiswa menyatakan mempunyai perangkat/sarana untuk melakukan praktikum di rumah, 8,1\% mahasiswa menyatakan sedikit kesulitan menyediakan perangkat/peralatan untuk melakukan praktikum di rumah dikarenakan kualitas yang kurang memadai. 5,4\% sangat kesulitan memiliki perangkat/peralatan tersebut dikarenakan keterbatasan kemampuan ekonomi.

Secara keseluruhan aspek sarana dan prasarana mendapatkan persentase rerata sebesar $80,1 \%$ sehingga dapat dikategorikan respon mahasiswa terhadap ketersedian sarana dan prasarana pada perkuliahan daring untuk mata kuliah praktik adalah positif.

\section{Grafik 10 Ketersediaan materi}

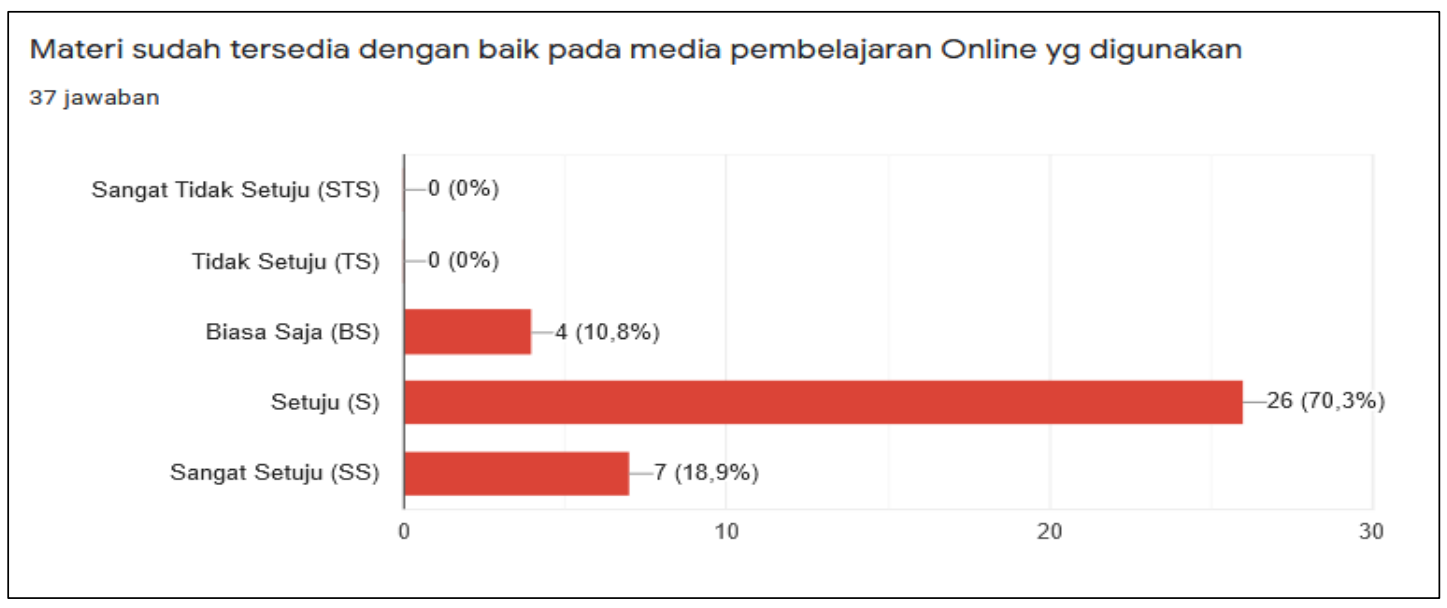

\section{Grafik 11 Ketersediaan sarana}

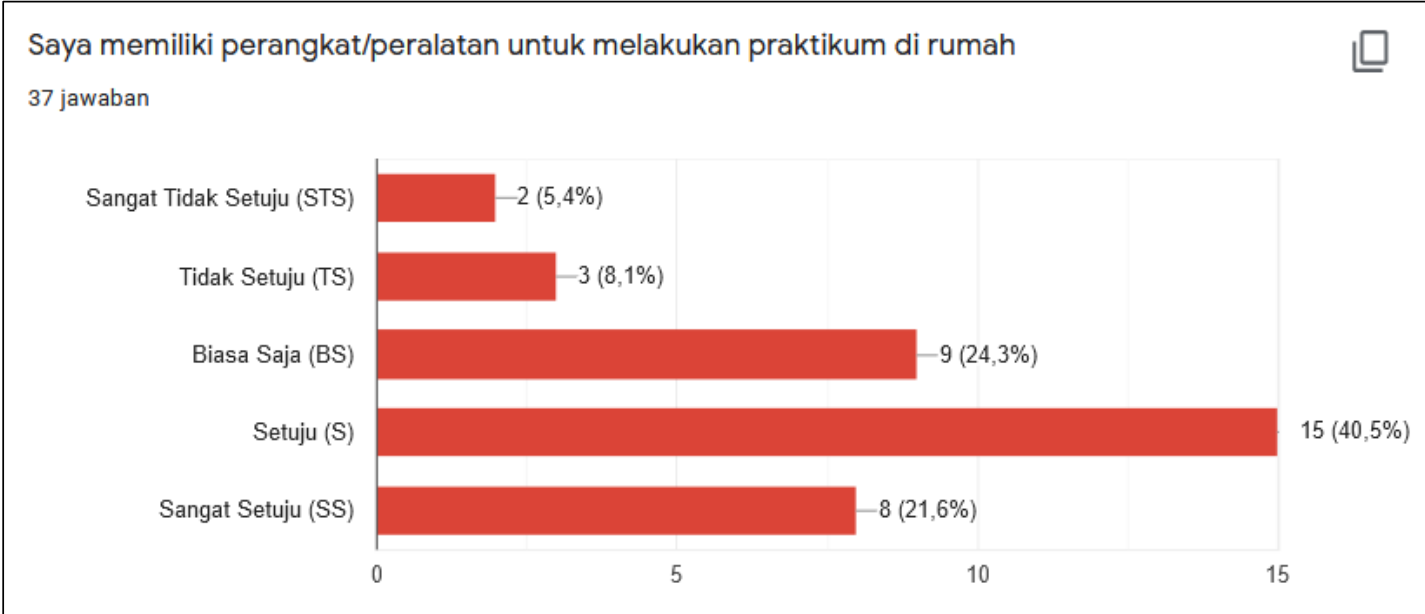

\subsection{Motivasi Mahasiswa}


Purnomo, D. J., Lewa, A. H., Asshofi, I. U. A., (2021). Analysis of Student Motivation in Online Learning for the Tourism and Hospitality Management Information System Course during the Covid-19 Pandemic. LITE: Jurnal Bahasa, Sastra, dan Budaya 17 (2), 1-20. https://doi.org/10.33633/lite.v17i2.5061

Motivasi diartikan sebagai kekuatan (energi) seseorang yang dapat menimbulkan tingkat kemauan dalam melaksanakan suatu kegiatan (Suprihatin, 2015). Respon positif dari aspek perkuliahan, kemampuan dosen, sarana dan prasarana juga berpengaruh positif terhadap motivasi mahasiswa dalam menjalani perkuliahan daring. Tingkat keaktifan dan motivasi tinggi dengan rerata persentase kehadiran mahasiswa dalam 1 semester mencapai $92 \%$ dan pengumpulan tugas $85 \%$. motivasi mahasiswa tersebut dilihat dari aktivitas perkuliahan menggunakan sistem aplikasi pembelajaran daring yang digunakan (tabel 5.)

\section{Tabel 3: Presensi mahasiswa kelompok C13.1.1 \\ [Sumber: kulino.dinus.ac.id]}

Course [20201] TOURISM AND HOSPTALTTY MANAGEMENT INFORMATION SYSTEM - C13.3.1

Group All participants

\begin{tabular}{|c|c|c|c|c|c|c|c|c|c|c|c|c|c|c|c|c|c|c|c|c|c|}
\hline Student ID & $\begin{array}{l}29 \text { Sep } \\
2020 \\
8.40 \text { AM All } \\
\text { students }\end{array}$ & $\begin{array}{l}60 \text { ct } 2020 \\
8.40 \text { AM All } \\
\text { students }\end{array}$ & $\begin{array}{l}13 \text { Oct } \\
2020 \\
8.40 \mathrm{AM} \text { All } \\
\text { students }\end{array}$ & $\begin{array}{l}20 \text { Oct } \\
2020 \\
8.40 \mathrm{Am} \text { All } \\
\text { students }\end{array}$ & $\begin{array}{l}27 \text { Oct } \\
2020 \\
8.40 \text { AM All } \\
\text { students }\end{array}$ & $\begin{array}{l}3 \text { Nov } 2020 \\
8.40 \text { AM All } \\
\text { students }\end{array}$ & $\begin{array}{l}10 \text { Nov } \\
2020 \\
8.40 \text { AM All } \\
\text { students } \\
\end{array}$ & $\begin{array}{l}17 \text { Nov } \\
2020 \\
8.40 \text { AM All } \\
\text { students } \\
\end{array}$ & $\begin{array}{l}24 \text { Nov } \\
2020 \\
8.40 \text { AM All } \\
\text { students } \\
\end{array}$ & $\begin{array}{l}1 \text { Dec } 2020 \\
8.40 \mathrm{AM} \text { All } \\
\text { students }\end{array}$ & $\begin{array}{l}8 \mathrm{Dec} 2020 \\
8.40 \mathrm{AM} \text { All } \\
\text { students }\end{array}$ & $\begin{array}{l}15 \mathrm{Dec} \\
2020 \\
8.40 \mathrm{Am} \text { All } \\
\text { students }\end{array}$ & $\begin{array}{l}22 \mathrm{Dec} \\
2020 \\
8.40 \mathrm{Am} \text { All } \\
\text { students }\end{array}$ & $\begin{array}{l}29 \text { Dec } \\
2020 \\
8.40 \mathrm{Am} \text { All } \\
\text { students }\end{array}$ & $P$ & $\mathrm{~L}$ & E & A & $\begin{array}{l}\text { Taken } \\
\text { sessions }\end{array}$ & Points & $\begin{array}{c}\text { Percen } \\
\text { tage }\end{array}$ \\
\hline 13718 & $\mathrm{~L}(1 / 2)$ & $P(2 / 2)$ & $?$ & $\mathrm{P}(2 / 2)$ & $P(2 / 2)$ & $P(2 / 2)$ & $P(2 / 2)$ & $P(2 / 2)$ & $P(2 / 2)$ & $E(1 / 2)$ & $\mathrm{P}(2 / 2)$ & $\mathrm{P}(2 / 2)$ & $P(2 / 2)$ & $?$ & 10 & 1 & 1 & 0 & 12 & $22 / 24$ & 91,7 \\
\hline 13720 & $P(2 / 2)$ & $P(2 / 2)$ & $P(2 / 2)$ & $P(2 / 2)$ & $A(0 / 2)$ & $P(2 / 2)$ & $P(2 / 2)$ & $P(2 / 2)$ & $P(2 / 2)$ & $\mathrm{P}(2 / 2)$ & $\mathrm{P}(2 / 2)$ & $\mathrm{P}(2 / 2)$ & $P(2 / 2)$ & $P(2 / 2)$ & 13 & 0 & 0 & 1 & 14 & $26 / 28$ & 92,9 \\
\hline 13716 & $?$ & $P(2 / 2)$ & $L(1 / 2)$ & $A(0 / 2)$ & $P(2 / 2)$ & $P(2 / 2)$ & $?$ & $E(1 / 2)$ & $\mathrm{P}(2 / 2)$ & $\mathrm{P}(2 / 2)$ & $E(1 / 2)$ & $E(1 / 2)$ & $A(0 / 2)$ & $?$ & 5 & 1 & 3 & 2 & 11 & $14 / 22$ & 63,6 \\
\hline 13717 & $\mathrm{P}(2 / 2)$ & $P(2 / 2)$ & $\mathrm{P}(2 / 2)$ & $\mathrm{P}(2 / 2)$ & $P(2 / 2)$ & $P(2 / 2)$ & $P(2 / 2)$ & $\mathrm{P}(2 / 2)$ & $\mathrm{P}(2 / 2)$ & $\mathrm{P}(2 / 2)$ & $\mathrm{P}(2 / 2)$ & $\mathrm{P}(2 / 2)$ & $P(2 / 2)$ & $P(2 / 2)$ & 14 & 0 & 0 & 0 & 14 & $28 / 28$ & 100 \\
\hline 13726 & $\mathrm{P}(2 / 2)$ & $\mathrm{P}(2 / 2)$ & $\mathrm{P}(2 / 2)$ & $\mathrm{P}(2 / 2)$ & $\mathrm{P}(2 / 2)$ & $P(2 / 2)$ & $\mathrm{P}(2 / 2)$ & $\mathrm{P}(2 / 2)$ & $\mathrm{P}(2 / 2)$ & $\mathrm{P}(2 / 2)$ & $\mathrm{P}(2 / 2)$ & $\mathrm{P}(2 / 2)$ & $\mathrm{P}(2 / 2)$ & $\mathrm{P}(2 / 2)$ & 14 & 0 & 0 & 0 & 14 & $28 / 28$ & 100 \\
\hline 13745 & $P(2 / 2)$ & $P(2 / 2)$ & $P(2 / 2)$ & $P(2 / 2)$ & $P(2 / 2)$ & $P(2 / 2)$ & $E(1 / 2)$ & $\mathrm{P}(2 / 2)$ & $P(2 / 2)$ & $\mathrm{P}(2 / 2)$ & $\mathrm{P}(2 / 2)$ & $\mathrm{P}(2 / 2)$ & $P(2 / 2)$ & $P(2 / 2)$ & 13 & 0 & 1 & 0 & 14 & $27 / 28$ & 96,4 \\
\hline 13731 & $P(2 / 2)$ & $P(2 / 2)$ & $P(2 / 2)$ & $\mathrm{P}(2 / 2)$ & $P(2 / 2)$ & $P(2 / 2)$ & $P(2 / 2)$ & $P(2 / 2)$ & $P(2 / 2)$ & $\mathrm{P}(2 / 2)$ & $\mathrm{P}(2 / 2)$ & $\mathrm{P}(2 / 2)$ & $P(2 / 2)$ & $P(2 / 2)$ & 14 & 0 & 0 & 0 & 14 & $28 / 28$ & 100 \\
\hline 13723 & $P(2 / 2)$ & $P(2 / 2)$ & $\mathrm{P}(2 / 2)$ & $\mathrm{P}(2 / 2)$ & $\mathrm{P}(2 / 2)$ & $P(2 / 2)$ & $P(2 / 2)$ & $P(2 / 2)$ & $P(2 / 2)$ & $\mathrm{P}(2 / 2)$ & $\mathrm{P}(2 / 2)$ & $\mathrm{P}(2 / 2)$ & $P(2 / 2)$ & $A(0 / 2)$ & 13 & 0 & 0 & 1 & 14 & $26 / 28$ & 92,9 \\
\hline 13712 & $L(1 / 2)$ & $\mathrm{P}(2 / 2)$ & $\mathrm{P}(2 / 2)$ & $\mathrm{P}(2 / 2)$ & $\mathrm{P}(2 / 2)$ & $\mathrm{P}(2 / 2)$ & $\mathrm{P}(2 / 2)$ & $?$ & $P(2 / 2)$ & $\mathrm{P}(2 / 2)$ & $\mathrm{P}(2 / 2)$ & $\mathrm{P}(2 / 2)$ & $\mathrm{P}(2 / 2)$ & $\mathrm{P}(2 / 2)$ & 12 & 1 & 0 & 0 & 13 & $25 / 26$ & 96,2 \\
\hline 13735 & $P(2 / 2)$ & $P(2 / 2)$ & $P(2 / 2)$ & $E(1 / 2)$ & $P(2 / 2)$ & $P(2 / 2)$ & $P(2 / 2)$ & $A(0 / 2)$ & $P(2 / 2)$ & $\mathrm{L}(1 / 2)$ & $E(1 / 2)$ & $P(2 / 2)$ & $E(1 / 2)$ & $P(2 / 2)$ & 9 & 1 & 3 & 1 & 14 & $22 / 28$ & 78,6 \\
\hline 13736 & $E(1 / 2)$ & $P(2 / 2)$ & $P(2 / 2)$ & $?$ & $P(2 / 2)$ & $P(2 / 2)$ & $?$ & $?$ & $?$ & $?$ & $?$ & $?$ & $?$ & $?$ & 4 & 0 & 1 & 0 & 5 & $9 / 10$ & 90 \\
\hline 13721 & $?$ & $P(2 / 2)$ & $P(2 / 2)$ & $P(2 / 2)$ & $\mathrm{P}(2 / 2)$ & $P(2 / 2)$ & $P(2 / 2)$ & $?$ & $?$ & $\mathrm{P}(2 / 2)$ & $\mathrm{P}(2 / 2)$ & $\mathrm{P}(2 / 2)$ & $P(2 / 2)$ & $P(2 / 2)$ & 11 & 0 & 0 & 0 & 11 & $22 / 22$ & 100 \\
\hline 13711 & $P(2 / 2)$ & $P(2 / 2)$ & $P(2 / 2)$ & $P(2 / 2)$ & $P(2 / 2)$ & $P(2 / 2)$ & $P(2 / 2)$ & $P(2 / 2)$ & $P(2 / 2)$ & $\mathrm{P}(2 / 2)$ & $\mathrm{P}(2 / 2)$ & $\mathrm{P}(2 / 2)$ & $P(2 / 2)$ & $P(2 / 2)$ & 14 & 0 & 0 & 0 & 14 & $28 / 28$ & 100 \\
\hline 13719 & $E(1 / 2)$ & $P(2 / 2)$ & $P(2 / 2)$ & $P(2 / 2)$ & $P(2 / 2)$ & $P(2 / 2)$ & $P(2 / 2)$ & $P(2 / 2)$ & $P(2 / 2)$ & $E(1 / 2)$ & $\mathrm{P}(2 / 2)$ & $\mathrm{P}(2 / 2)$ & $P(2 / 2)$ & $P(2 / 2)$ & 12 & 0 & 2 & 0 & 14 & $26 / 28$ & 92,9 \\
\hline 13709 & $P(2 / 2)$ & $E(1 / 2)$ & $?$ & $P(2 / 2)$ & $P(2 / 2)$ & $P(2 / 2)$ & $P(2 / 2)$ & $?$ & $P(2 / 2)$ & $?$ & $\mathrm{P}(2 / 2)$ & $\mathrm{P}(2 / 2)$ & $P(2 / 2)$ & $P(2 / 2)$ & 10 & 0 & 1 & 0 & 11 & $21 / 22$ & 95,5 \\
\hline 13737 & $E(1 / 2)$ & $P(2 / 2)$ & $P(2 / 2)$ & $P(2 / 2)$ & $P(2 / 2)$ & $A(0 / 2)$ & $?$ & $P(2 / 2)$ & $P(2 / 2)$ & $\mathrm{P}(2 / 2)$ & $\mathrm{P}(2 / 2)$ & $P(2 / 2)$ & $P(2 / 2)$ & $P(2 / 2)$ & 11 & 0 & 1 & 1 & 13 & $23 / 26$ & 88,5 \\
\hline 13715 & $P(2 / 2)$ & $P(2 / 2)$ & $\mathrm{P}(2 / 2)$ & $\mathrm{P}(2 / 2)$ & $\mathrm{P}(2 / 2)$ & $P(2 / 2)$ & $E(1 / 2)$ & $\mathrm{P}(2 / 2)$ & $P(2 / 2)$ & $\mathrm{P}(2 / 2)$ & $\mathrm{P}(2 / 2)$ & $\mathrm{P}(2 / 2)$ & $P(2 / 2)$ & $P(2 / 2)$ & 13 & 0 & 1 & 0 & 14 & $27 / 28$ & 96,4 \\
\hline 13742 & $\mathrm{P}(2 / 2)$ & $\mathrm{P}(2 / 2)$ & $\mathrm{P}(2 / 2)$ & $?$ & $E(1 / 2)$ & $\mathrm{P}(2 / 2)$ & $\mathrm{P}(2 / 2)$ & $?$ & $\mathrm{P}(2 / 2)$ & $\mathrm{P}(2 / 2)$ & $\mathrm{P}(2 / 2)$ & $\mathrm{P}(2 / 2)$ & $\mathrm{P}(2 / 2)$ & $P(2 / 2)$ & 11 & 0 & 1 & 0 & 12 & $23 / 24$ & 95,8 \\
\hline 13710 & $P(2 / 2)$ & $\mathrm{P}(2 / 2)$ & $P(2 / 2)$ & $\mathrm{P}(2 / 2)$ & $\mathrm{P}(2 / 2)$ & $P(2 / 2)$ & $E(1 / 2)$ & $\mathrm{P}(2 / 2)$ & $\mathrm{P}(2 / 2)$ & $P(2 / 2)$ & $P(2 / 2)$ & $P(2 / 2)$ & $P(2 / 2)$ & $P(2 / 2)$ & 13 & 0 & 1 & 0 & 14 & $27 / 28$ & 96,4 \\
\hline 13733 & $P(2 / 2)$ & $P(2 / 2)$ & $\mathrm{P}(2 / 2)$ & $\mathrm{P}(2 / 2)$ & $\mathrm{P}(2 / 2)$ & $P(2 / 2)$ & $P(2 / 2)$ & $P(2 / 2)$ & $P(2 / 2)$ & $\mathrm{P}(2 / 2)$ & $\mathrm{P}(2 / 2)$ & $\mathrm{P}(2 / 2)$ & $P(2 / 2)$ & $P(2 / 2)$ & 14 & 0 & 0 & 0 & 14 & $28 / 28$ & 100 \\
\hline 13724 & $L(1 / 2)$ & $P(2 / 2)$ & $P(2 / 2)$ & $\mathrm{P}(2 / 2)$ & $P(2 / 2)$ & $P(2 / 2)$ & $P(2 / 2)$ & $?$ & $P(2 / 2)$ & $P(2 / 2)$ & $\mathrm{P}(2 / 2)$ & $P(2 / 2)$ & $P(2 / 2)$ & $P(2 / 2)$ & 12 & 1 & 0 & 0 & 13 & $25 / 26$ & 96,2 \\
\hline 13730 & $?$ & $L(1 / 2)$ & $?$ & $?$ & $L(1 / 2)$ & $?$ & $?$ & $?$ & $?$ & $?$ & $?$ & $?$ & $?$ & $?$ & 0 & 2 & 0 & 0 & 2 & $2 / 4$ & 50 \\
\hline
\end{tabular}

Tabel 4: Presensi mahasiswa kelompok C13.1.2

[Sumber: kulino.dinus.ac.id]

Course [20201] TOURISM AND HOSPTALITY MANAGEMENT INFORMATION SYSTEM - C13.3.2

Group All participants

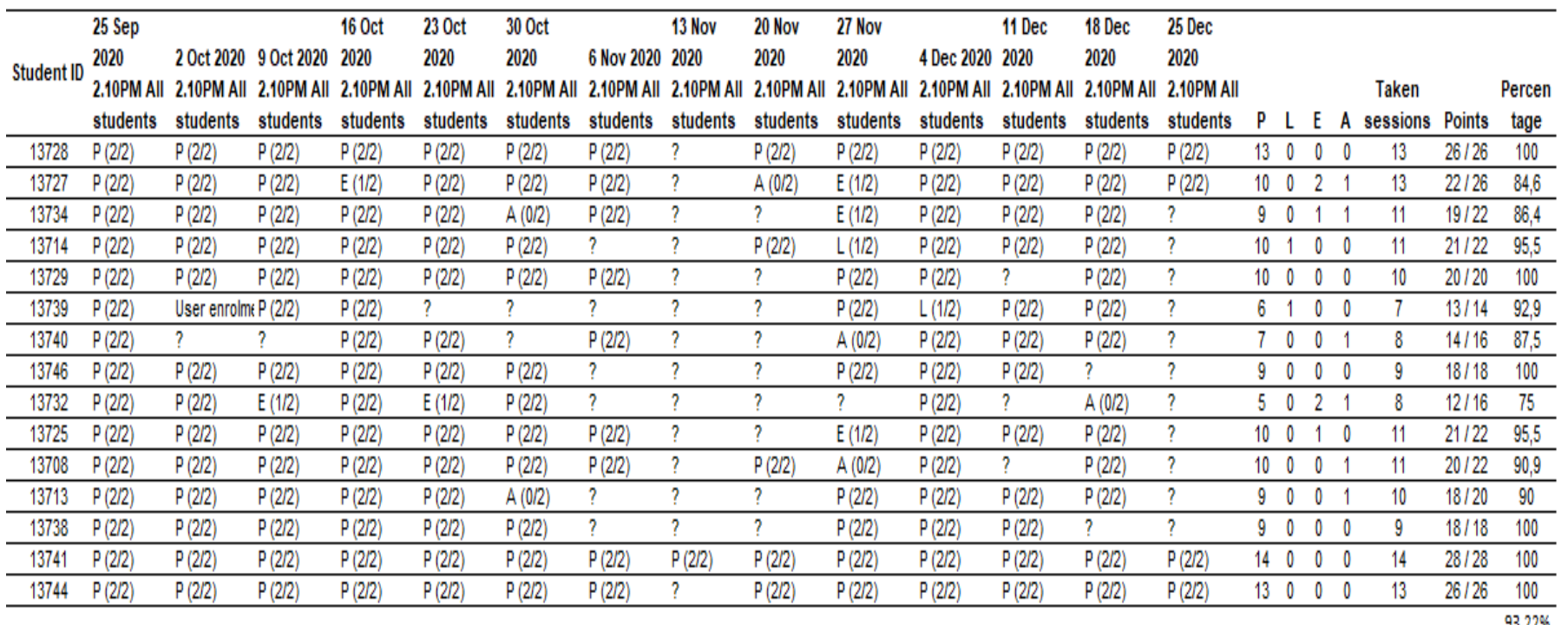


Purnomo, D. J., Lewa, A. H., Asshofi, I. U. A., (2021). Analysis of Student Motivation in Online Learning for the Tourism and Hospitality Management Information System Course during the Covid-19 Pandemic. LITE: Jurnal Bahasa, Sastra, dan Budaya 17 (2), 1-20. https://doi.org/10.33633/lite.v17i2.5061

Tabel 5: Tugas mahasiswa kelompok C13.1.1 [Sumber: kulino.dinus.ac.id]

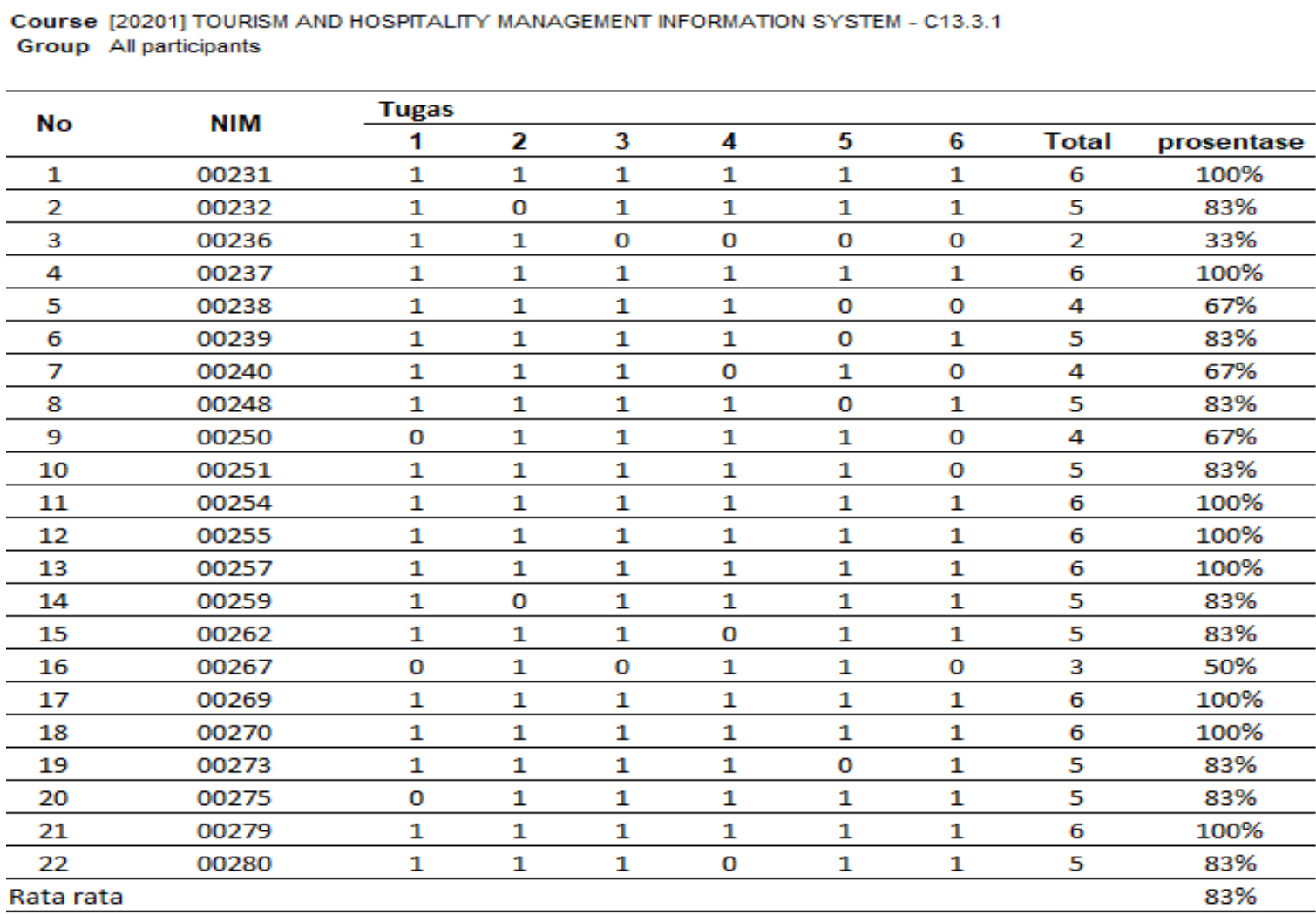

Tabel 5: Tugas mahasiswa kelompok C13.1.2

[Sumber: kulino.dinus.ac.id]

Course [20201] TOURISM AND HOSPTALITY MANAGEMENT INFORMATION SYSTEM - C13.3.2 Group All participants

\begin{tabular}{|c|c|c|c|c|c|c|c|c|c|}
\hline \multirow{2}{*}{ No } & \multirow{2}{*}{ NIM } & \multicolumn{8}{|c|}{ Tugas } \\
\hline & & 1 & 2 & 3 & 4 & 5 & 6 & Total & prosentase \\
\hline 1 & 00234 & 1 & 1 & 1 & 0 & 1 & 1 & 5 & $83 \%$ \\
\hline 2 & 00235 & 0 & 1 & 1 & 1 & 1 & 1 & 5 & $83 \%$ \\
\hline 3 & 00242 & 1 & 0 & 1 & 0 & 1 & 1 & 4 & $67 \%$ \\
\hline 4 & 00252 & 0 & 1 & 1 & 1 & 1 & 1 & 5 & $83 \%$ \\
\hline 5 & 00253 & 1 & 1 & 1 & 1 & 1 & 1 & 6 & $100 \%$ \\
\hline 6 & 00256 & 0 & 1 & 1 & 1 & 1 & 1 & 5 & $83 \%$ \\
\hline 7 & 00258 & 1 & 1 & 1 & 1 & 1 & 1 & 6 & $100 \%$ \\
\hline 8 & 00261 & 0 & 1 & 1 & 1 & 1 & 1 & 5 & $83 \%$ \\
\hline 9 & 00264 & 1 & 1 & 1 & 1 & 1 & 1 & 6 & $100 \%$ \\
\hline 10 & 00265 & 0 & 1 & 1 & 1 & 1 & 1 & 5 & $83 \%$ \\
\hline 11 & 00266 & 1 & 1 & 0 & 1 & 1 & 1 & 5 & $83 \%$ \\
\hline 12 & 00271 & 0 & 1 & 1 & 1 & 1 & 1 & 5 & $83 \%$ \\
\hline 13 & 00272 & 1 & 1 & 1 & 1 & 1 & 1 & 6 & $100 \%$ \\
\hline 14 & 00274 & 1 & 1 & 1 & 1 & 0 & 1 & 5 & $83 \%$ \\
\hline 15 & 00276 & 1 & 1 & 0 & 1 & 1 & 1 & 5 & $83 \%$ \\
\hline ata $\mathrm{r}$ & & & & & & & & & $87 \%$ \\
\hline
\end{tabular}




\section{Simpulan}

Perkuliahan daring adalah salah satu solusi di tengah pandemi saat ini, terlebih jurusan vokasi yang persentase praktik lebih besar dibandingkan teori dan mengutamakan penguasaan keterampilan. Untuk meningkatkan motivasi belajar mahasiswa, aspek proses perkuliahan, kemampuan dosen dan sarana prasarana harus ditingkatkan. Respon positif dari aspek perkuliahan, kemampuan dosen, sarana dan prasarana juga berpengaruh positif terhadap motivasi mahasiswa dalam menjalani perkuliahan daring. Tingkat keaktifan dan motivasi tinggi dengan rerata persentase kehadiran mahasiswa dalam 1 semester mencapai 92\% dan pengumpulan tugas $85 \%$. Akan tetapi, kemampuan secara finansial mahasiswa yang terbatas dan kondisi geografis dengan koneksi internet yang minim menjadi kendala utama dari perkuliahan daring.

\section{Referensi}

Emmilia, R., \& Nugroho, A. (2020). Respon Mahasiswa Pada Pembelajaran Daring Bagi Mahasiswa Mata Kuliah Pengantar Hukum Indonesia UNESA. INTEGRALISTIK, 31(1).

Firman, \& Rahman, S. R. (2020). Pembelajaran Online di Tengah Pandemi Covid-19. Indonesian Journal of Educational Science (IJES), 02(02).

Fitriani, Y., Fauzi, I., \& Sari, M. Z. (2020, Juli). Motivasi Belajar Mahasiswa Pada Pembelajaran Daring Selama Pandemik Covid-19. Jurnal Kependidikan, Vol.6, 165-175.

Maudiarti, S. (2018). Penerapan e-Learning di Perguruan Tinggi. PERSPEKTIF, 32(1).

Maulana, H. A., \& Hamidi, M. (2020). Persepsi Mahasiswa terhadap Pembelajaran Daring pada Mata Kuliah Praktik di Pendidikan Vokasi. Equilibrium, VIII(2. Juni - Desember 2020).

Noveandini, R., \& Wulandari, S. M. (2010). Pemanfaatan media pembelajaran secara online (elearning) bagi wanita karir dalam upaya meningkatkan efektivitas dan fleksibilitas pemantauan kegiatan belajar anak siswa/i sekolah dasar. SNATI 2010. Yogyakarta.

Rahayu, s. (2019, November). Manajemen Sarana dan Prasarana Pendidikan. INA-Rxiv.

Sofiana, L., \& Rozaq, A. (2019). Pembelajaran Daring Kombinasi Berbasis Whatsapp pada Kelas Karyawan Prodi Teknik Informatika Universitas PGRI Madiun. JANAPATI, 8(1).

Sugiyono. (2018). Metode Penelitian Kuantitatif, Kualitatif dan R\&D. Bandung: CV. Alfabeta.

Suprihatin, S. (2015). Upaya guru dalam meningkatkan motivasi belajar siswa. PROMOSI, 3(1), 73 82.

Tantri, N. R. (2018). Kehadiran Sosial dalam Pembelajaran Daring Berdasarkan Sudut Pandang. Jurnal Pendidikan Jarak Jauh.

https://sevima.com. (2019, September). Retrieved from https://sevima.com: https://sevima.com/mengenal-kuliah-online-kelebihan-dan-kekurangannya/

https://www.kemdikbud.go.id. (2020, Maret 12). Retrieved from https://www.kemdikbud.go.id: https://www.kemdikbud.go.id/main/blog/2020/03/sikapi-covid19-kemendikbud-terbitkandua-surat-edaran

https://www.kompas.com. (2020, 06). Retrieved from https://www.kompas.com: https://www.kompas.com/edu/read/2020/06/16/103917571/mendikbud-perguruan-tinggi-disemua-zona-dilarang-kuliah-tatap-muka

https://www.tribunnewswiki.com. (2020, Desember). Retrieved from https://www.tribunnewswiki.com: https://www.tribunnewswiki.com/2020/06/29/dampakpandemi-covid-19-perguruan-tinggi-indonesia-disebut-bisa-mati-terdampak-berikutalasannya?page $=$ all 